Fecha de recepción: diciembre 2018 Fecha de aceptación: febrero 2019 Versión final: mayo 2019

\section{Interaction with water in nature and self-cleaning potential of biological materials and species}

Carlo Santulli *

\begin{abstract}
Self-cleaning is an important characteristics of many biological species, considerably investigated in the biomimetic literature, with the aim to offer it into innovative materials. To try to summarize the different properties of bio-inspired materials having self-cleaning effect, different modes of classification have been proposed. In particular, either a paradigmatic species is cited, for example "lotus effect", "rose petal effect", etc., or a physical property is mentioned, such as super-hydrophobicity, super-oleophobicity, etc. This work considers some different modes in which nature implements self-cleaning as a form of effective interaction with water, depending on the respective needs of the various species. With this aim, a sample of ten species, selected among those which have been more investigated in biomimetic literature, have been considered. An attempt of classification is then given, trying to offer information for the development of new materials inspired from nature offering self-cleaning properties in different conditions of application.
\end{abstract}

Key words: Self-cleaning - biological species - biomimetic literature - materials - nature

[Resúmenes en español y portugués en la página 160]

(*) Associate professor of Materials Science and Technology in Università degli Studi di Camerino, where he lectures on materials science and experimentation to industrial designers. His research interests are on composite materials and nanocomposites, natural fibres and sustainable materials, waste upcycling, bio-inspired design and biomimetics. His book on biomimetics ("Biomimetica: la lezione della natura") is also available in English and Spanish. He also acts in dissemination of environmental and sustainability themes in schools and other contexts in Italy.

\title{
Introduction
}

During last decades, bio-inspiration has been considered as a central topic into material experience. This has brought to the development of biomimetic products, mainly based on nanotechnology. AskNature.org database lists over 2000 cases of success in problem 
solving through the use of biomimetics (Deldin \& Schucknecht 2013). This wealth of possibilities offers to the designer the opportunity to solve some issues of considerable importance during the service life of the design object, in particular interaction with water, air and light, as well as with other objects. It was suggested that this vision of problem-solving through biomimetics is based on the assumption that the capacities of any natural species indicate that a potential exists, which was designed and engineered already to work in the world (Johnson 2010). In other words, if a creature exists that has some abilities, it is possible to transfer them to solve some problem in human life, resulting in improved environmental and social sustainability, therefore consuming less energy while easing our work. However, after assessing that this ability exists in some species, it needs to be translated in a biomimetic solution. This process may not be straightforward: also, bio-inspiration requires a metaphorical approach. The limit of this approach was perceived already in early literature for example about biomimetic actuators, viewing enzymes as "molecular machines", so that cell biology could really and directly inspire technology (Knoblauch \& Peters 2004). The metaphor of describing functions in an individual like machines, which therefore perform mechanical actions to produce effects, was demonstrated to be not completely effective to represent how nature works. In practice, this approach led in most cases to using nanotechnology to produce synthetically patterned materials to mimic one single characteristic artificially isolated from the inspiring species, for example structural color or bioluminescence. It has also been suggested that the biomimetic approach could be more effective by adhering more strictly to the biological principle of production. A possibility would be introducing a real molecular assembly, therefore starting from the molecule to build the structure, for example developing a rapid prototyping machine equipped with "spinnerets" based on those found in a spider or in a caterpillar (Vincent 2014). In more general terms, nature has demonstrated to be able to design using and adapting a limited number of materials to its needs, while designers tend to multiply the number of materials and constructive solutions.

The consequence of the above considerations is that the relation between obtaining biomimetic products and improving sustainability can be sometimes questionable. A first observation is that mostly synthetic materials are used to obtain the bio-inspired effect, end-of-life scenarios are not always investigated and in most cases bear no relation with obtaining the desired biomimetic effect. As an example, the so called "lotus effect" i.e., a very high contact angle at the boundary between water droplet and the material surface, also referred to as "super-hydrophobicity", is effectively obtained using synthetic polymers, such as polydimethylsiloxane (PDMS). PDMS was effectively used in micro-replication of shark skin surface, showing super-hydrophobic properties (Liu and Li 2012). The recyclability of PDMS crosslinked with trans-esterification process was investigated and proved quite feasible at $180^{\circ} \mathrm{C}$, maintaining properties even after 10 cycles and being usable for micro-patterning (Zhang et al., 2017): however, recyclability and super-hydrophobicity are two concepts not easily obtained on the same polymer, hence recyclable PDMS might not be as suitable for "lotus effect" purposes. "Lotus effect" could be obtained in a facilitated way with methods, excludingthe possibility of material recycling though, practically wrapping silica into a polyurethane substrate (Su 2010). Even more remote from natural materials are those proposed when trying to couple the lotus effect with other natural 
characteristics, for example structural color, as developed by butterflies, such as Morpho Rhetenor (Vukusic and Sambles 2003). In practice, to produce the combined effect, submicron-sized monodisperse polystyrene spheres and nanosized particles were ultrasonically dispersed into deionised water, immersing then a glass substrate into the solution and withdrawing it at a constant speed (Sato et al., 2009).

On the other side, sustainability would be achieved in an indirect way, in case the durability of the material is improved with respect to other materials without self-cleaning characteristics. To develop more effective biomimetic products, it is important to clarify what is the real benefit obtained by the species by some particular ability and what are the characteristics of the environment the species interacts with. In this work, the discussion concentrates on self-cleaning. This exigency is declined in different forms, usually schematized between two opposite ends, as super-hydrophobicity (contact angles higher than $90^{\circ}$, then leading to the discharge of water from the surface) or super-hydrophilicity, hence easy spreading of water over the surface. These could be exploited in the world of design, possibly applying in the future materials with production methods as close as possible to the natural ones, as suggested by Vincent (2014).

This work is aimed therefore at demonstrating, by briefly discussing a number of well known "case studies", how the benefits obtained by the vegetable or animal species in their environment can be described, and suggesting how biomimetic products could be developed according to this concept. The study concentrates therefore on the variation of contact angle, which can be intended in nature as leading to the general need of self-cleaning, which means removing contaminant, while promoting useful interaction with fluids. This requires from the biological species obtaining from the materials a complex interplay of surface chemistry, topography, and mechanical properties (Genzer and Marmur 2008). After this, some existing products or concept studies over the applicability of biomimetic ideas to self-cleaning surfaces are also presented and their limitations are discussed.

\section{Case Studies}

In most cases, the natural organism reacts to what occurs to it from the environment, in other words to the stimuli generated by the context surrounding it. Dealing with superhydrophobicity, a sounder analysis on lotus leaves clarified that in reality, from the measurement of the contact angle, the interaction with water is quite variable and does depend on the orientation of water droplets arriving to the surface (Cheng and Rodak 2005). This can be explained, thinking of the fact that in reality lotus leaves defend themselves from the environment surrounding them and it is possible that water droplets in some orientations are perceived as less "risky" for the leaf operation and survival than others. In other species, such as rice, leaves have the possibility, rather than varying the contact angle, to control the orientation of water droplet during their fall from the leaf surface due to superhydrophobicity (Wu et al., 2011). More information would come from the availability of specific observation methods of the time-lapse fall of different parts of the droplet on the leaf surface, which is not easy at this scale yet. 
This poses another question, which is the fact that a droplet not falling immediately, yet being released in a controlled time, may suggest the presence of some adhesion force. The combination of adhesion force with water with superhydrophobicity has been encountered in the case of gecko feet, where it has been attributed to the high density nanopillars that offer local pressure in contact with water (Autumn and Gravish 2008; Liu et al., 2012). The combined presence of super-hydrophobicity, when needed, with a reversible and time-controlled adhesion force, has been defined as the "rose petal effect". This has been translated in physical terms as a contact angle hysteresis, defined as the difference between advancing and receding effect (Bhushan \& Nosokovsky 2010). In the case of snail shells, the opposite phenomenon of super-hydrophilicity is reported. This results in water contact angle being equal to zero, and therefore being able to push water droplet on the surface, therefore resulting in a self-cleaning effect (Nishimoto \& Bhushan 2013). Selfcleaning can be added to improved personal hygiene, as it is in the case of cicada wings, where nanopatterns of the surface are able to decontaminate the insect from the presence of some bacteria by pure mechanical effect (Hasan et al., 2013). The approach followed in the situation of shark skin is in contrast due to the fact that the material in itself can be hydrophilic, yet a highly textured surface can provide contact angles close to $180^{\circ}$, and therefore superhydrophobic (Ball 1999). In some sense, it can be noticed that the two cases can be thought of as opposite to each other. In other cases, such as for fish scales, the selfcleaning effect only takes place in presence of a liquid with sufficiently high viscosity (oil), with a kind of anti-wetting behavior (Liu et al., 2010). This is generated by the fact that fish scales are made of a composite, which is externally tough (bone-like) and internally soft (collagenous). This is a solution frequently adopted in nature, for example for reasons of defense, yet with no objective of particular relation with water, from what is known so far, such as in porcupine quills (Vincent and Owers 1986). Highly textured surfaces can serve though also to other purposes, therefore as kind of reservoirs for wax, in which case they need to be arranged in a suitable way for this aim, in particular with hexagonal arrays of flattened hemispheres (Parker and Lawrence 2001). In this way, a water droplet forms quickly on the hydrophilic peak until it covers the entire waxy area until it rolls off the peak and down the angled elytra.

In the examples considered till now of interaction with water droplets, they are thought as subjected to some shear force, as it is the case for self-cleaning. It might also the case though that the contact takes place in compression mode, such as it happens when "walking" on water. In this case it is essential that the compression strength of the water surface layer is sufficient. Water strider solves this problem by exploiting the curvature of the water surface by propelling their central legs in a sculling position (Hu et al., 2003). This case demonstrates as the dimensional problem is essential, since the size of the water strider allows a very limited energy consumption, which is not the case when the dimensions are scaled up e.g., to those of a speedboat.

After having reasoned on the different cases of self-cleaning declinations into the relation with water, these will be exposed in the following Section as procedures to obtain selfcleaning. The objective of this evaluation would be trying to clarify whether the results achieved by the biological species can be of any interest in our common life problems, therefore resulting in the development of new bio-inspired devices. 


\section{Discussion on species with self-cleaning surfaces}

In Table 1 are reported the different species considered above and the characteristic, related to self-cleaning, that allowed them being studied into biomimetic literature. The species are all endowed with self-cleaning characteristics, but in different senses, as discussed in the Table. Apart from literature considered above, the consideration following have been related to the observation from Malik et al., (2014). The aforementioned study in particular considers self-cleaning as a specific aspect of a more general "moisture harvesting" capacity in nature, as a way of surviving the most different environmental conditions, which is of paramount importance also in design.

To try to summarize the different meanings of "self-cleaning" in the various species reported, which are only examples of the countless species that present this characteristics, some dichotomies between two adjectives, dry/wet, sticky/waxy, and curved/textured, have been reported. On the other side, the interaction with water has been considered as depending on the droplet geometry, its angle of fall on the surface, and its consistency. This last concept is aimed at including the mechanical resistance of fluid surface, fluid viscosity, and its contamination. The species considered are summed up into images in Figure 1, and the same images are reported as closer to one or the other concept evocated above in Figure 2, as an attempt of classification, which is given as a proposal and of course susceptible of further refinement.

More details are offered in Figure 3, where some characteristics are presented, which offer more information about the way in which self-cleaning is obtained by each of the ten species considered. In general yet quite imprecise terms, a common reference to lotus is made into design and products, indicating it as the archetypal species for self-cleaning. Being aware of the diversity of approaches adopted in nature for self-cleaning could assist the development of more tailored bio-inspired solutions for this purpose.

In particular, Figure 3 is aimed at integrating information offered above from recent studies on self-cleaning methods in nature. To summarize this information, some considerations can be done on factors, which can explain and differentiate the procedure adopted for self-cleaning. One factor is the presence of different levels: in the case of lotus leaves, their structure interacts with water, in different way depending on the falling angle of droplets, on the upper side, whereas it interacts with oils, being superoleophobic, on the lower side, which is normally immerse in water (Cheng et al., 2011). Surfaces built in levels with different mechanical properties are also used by rice leaves to effectively interact with the dirt particles and ultimately allowing them to drop down together with water (Wu et al., 2012). In rose petals, the effect due to the contact angle is also coupled to some adhesion due to air pressure obtained by the airflow generated by the travel itself of the droplet over the surface (Bhushan and Nosonovski 2010). The travelling effect of the droplet is also exploited by the cicada wing, the fish scales and the beetle elytra, although over different timescales, desiring an effective self-cleaning compatible with their speed of movement (Wisdom et al., 2013; Zhang et al., 2013; Dorrer and Rühe 2008). Other species, such as it is the case for snail shells, shark skins and water striders, base their self-cleaning potential over the fact that the droplets tend easily to lose balance on the non-uniform (spiraled or ribbed) surface structure (Bixler and Bhushan 2013). In the case of water strider, the com- 
plexity of leg setae, does offer the possibility to exploit the variable standing of water (Feng et al, 2007). The case of geckoes appear quite different, in the sense that the complex hierarchical structure brings to spatula terminations, able to offer a variable adhesion to the surface by Van Der Waals force, considering only the geometrical aspect of it and not the material by which it is formed (Autumn and Gravish, 2008; Hansen and Autumn 2005).

\begin{tabular}{|l|l|}
\hline \multicolumn{1}{|c|}{ Species } & \multicolumn{1}{c|}{ Characteristic } \\
\hline Lotus leaves & $\begin{array}{l}\text { Interaction with water (hydrophobic or hydrophilic) depending on the fa- } \\
\text { Iling angle of water droplets on it. This allows collecting dirt when the angle } \\
\text { is adapted to the purpose (slowly sliding droplet) }\end{array}$ \\
\hline Rice leaves & $\begin{array}{l}\text { Controlled falling angle due to superhydrophobicity; may be some adhe- } \\
\text { sion when needed }\end{array}$ \\
\hline Gecko foot & Adhesion force due to nanopillars morphology \\
\hline Rose petals & Super-hydrophobicity when needed but also controlled adhesion \\
\hline Snail shell & Superhydrophilic yet decontaminating each droplet \\
\hline Cicada wings & Antibacterial effect due to mechanical complexity of surface nanopattern \\
\hline Shark skin & Superhydrophobicity by surface patterns \\
\hline Fish scales & Composite, and self-cleaning only for liquids with sufficient viscosity \\
\hline Water strider & Self-cleaning yet exploiting the curvature of water surface for motion \\
\hline Beetle elytra & $\begin{array}{l}\text { Waxy textured surface with a hydrophilic peak, it attracts water droplet, } \\
\text { then it lets it down. }\end{array}$ \\
\hline
\end{tabular}

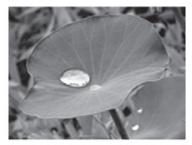

LOTUS LEAF

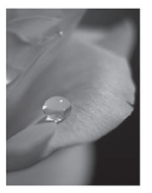

ROSE PETAL

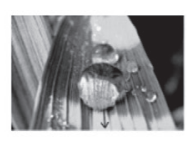

RICE LEAF

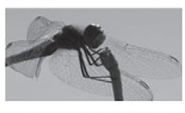

CICADA WINGS

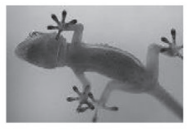

GECKO

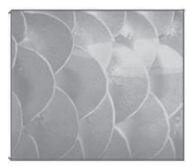

FISH SCALES

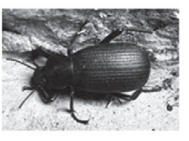

DESERT BEETLE

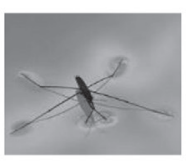

WATER STRIDER

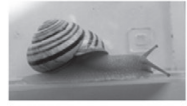

SNAIL SHELL

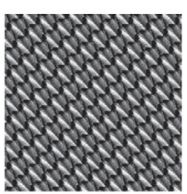

SHARK SKIN

Figure 1. Species considered for their self-cleaning skills 


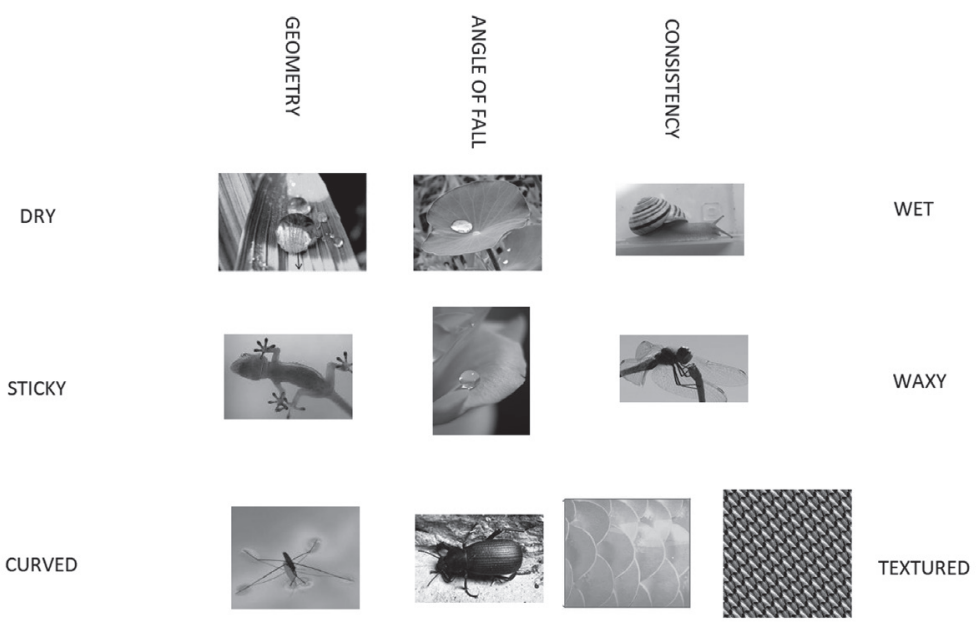

Figure 2. Species considered in terms of the "method" they apply, expressed by couples of adjectives, to achieve self-cleaning

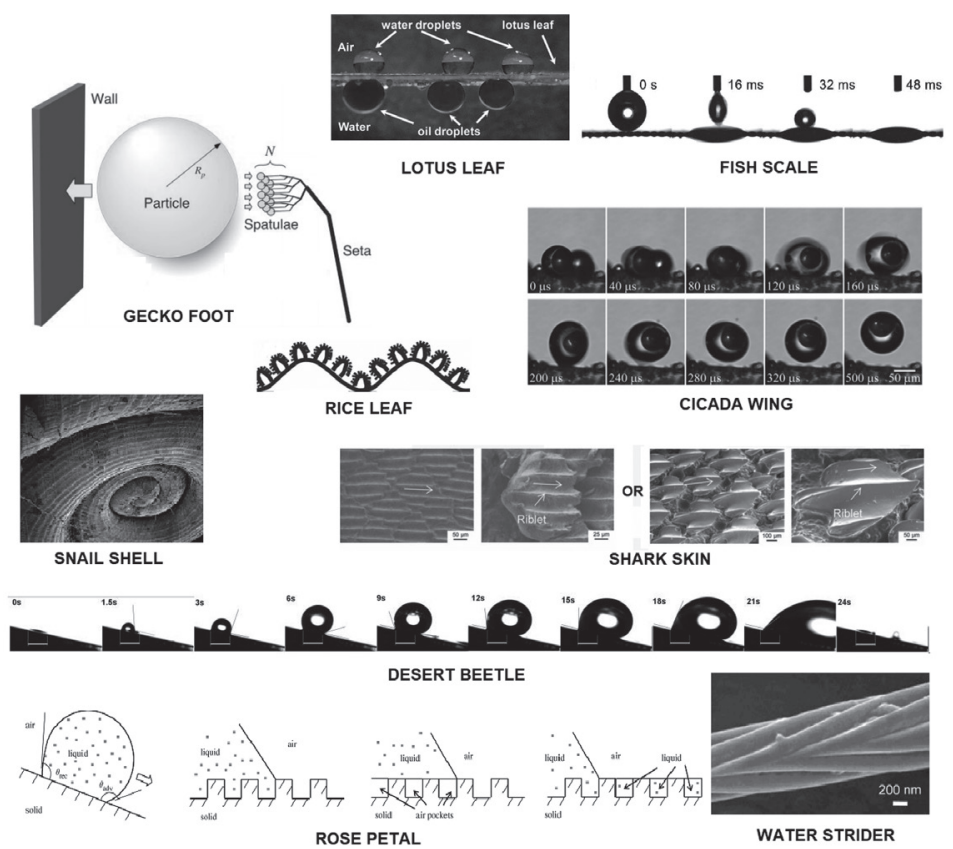

Figure 3. Details of structures/methods for obtaining self-cleaning in the different species considered 


\section{Conclusions}

A large variety of modes exists, in which nature performs self-cleaning as a form of effective interaction with water (and more generally fluids), which depend on the respective needs of the various species during their interaction with the environment. In practical terms, self-cleaning characteristics would depend on how the fluid impacts on the surface (contact angle, velocity, etc.) and on its very characteristics (viscosity, contamination, etc.). A sample of ten species has been considered, which have been selected among those more intensely investigated in biomimetic literature. The purpose of the classification offered as an example is to give information for the development of new materials with selfcleaning properties in different conditions, as inspired from nature. The results obtained are aimed at offering guidance on the design and development of bio-inspired materials with behavior more responsive to the real needs of the specific situation encountered in material operation during service.

\section{References}

Autumn K, Gravish N (2008), Gecko adhesion: evolutionary nanotechnology, Phylosophical Transactions of the Royal Society A 366, pp. 1575-1590.

Ball P, (1999) Engineering shark skin and other solutions, Nature 400, 5 August 1999, pp. 507-509.

Bixler GD, Bhushan B, (2013) Fluid drag reduction with shark-skin riblet inspired microstructured surfaces, Advanced Functional Materials 23, pp. 4507-4528.

Bhushan B, Nosonovsky M, (2010) The rose petal effect and the modes of superhydrophobicity, Phylosophical Transactions of the Royal Society A 368 (1929), 28 October 2010, pp. 4713-4728.

Cheng Q, Li M, Zheng Y, Su B, Wang S, Jiang L, (2011) Janus interface materials: superhydrophobic air/solid interface and superoleophobic water/solid interface inspired by a lotus leaf, Soft Matter 7, pp. 5948-5951.

Cheng Y-T, (2005) Rodak DE, Is the lotus leaf superhydrophobic?, Applied Physics Letters 86.

Deldin J-M, Schuknecht M, (2013) The AskNature database: enabling solutions in biomimetic design, Biologically Inspired Design, Computational Methods and Tools, Goel, AK, McAdams DA, Stone R.B (eds.), Springer, pp. 17-27.

Dorrer C, Rühe J, (2008) Mimicking the Stenocara beetle's dewetting of drops from a patterned superhydrophobic surface, Langmuir 24, 6154-6158.

Feng XQ, Gao X, Wu Z, Jiang L, Zheng QS, (2007) Superior water repellency of water strider legs with hierarchical structures: experiments and analysis, Langmuir 23, 23, 4892-4896.

Genzer J, Marmur A, (2008) Biological and synthetic self-cleaning surfaces, MRS Bulletin 33, pp. 742-746.

Hansen WR, Autumn K, (2005) Evidence for self-cleaning in gecko setae, PNAS 102 (2), 385-389. 
Hasan J, Webb HK, Truong VK, Pogodin S, Baulin VA, Watson GS, Watson JA, Crawford RJ, Ivanova EP, (2013) Selective bactericidal activity of nanopatterned superhydrophobic cicada Psaltoda claripennis wing surfaces, Applied Microbiology and Biotechnology 97 (20), pp. 9257-9262.

Hu DL, Chan B, Bush JWM, (2003) The hydrodynamics of water strider locomotion, Nature 424, 7 August, pp. 663-666.

Jiang T, Guo Z, Liu W, (2015) Biomimetic superoleophobic surfaces: focusing on their fabrication and applications, Journal of Materials Chemistry A 3, pp. 1811-1827.

Johnson ER, (2010) Reinventing biological life, reinventing 'the human', Ephemera 10 (2),, pp. 177-193.

Knoblauch M, Peters WS, (2004) Biomimetic actuators: where technology and cell biology merge, Cellular and Molecular Life Sciences 61 (19-20), pp. 2497-2509.

Liu M, Zheng Y, Zhai J Jiang L, (2010) Bioinspired super-antiwetting interfaces with special liquid-solid adhesion, Accounts of Chemical Research 43 (3), pp. 368-377.

Liu Y, Li G, (2012) A new method for producing "Lotus Effect" on a biomimetic shark skin, Journal of Colloid and Interface Science 338 (1), pp. 235-242.

Malik FT, Clement RM, Gethin DT, Krawszik W, Parker AR, (2014) Nature's moisture harvesters: a comparative review, Bioinspiration \& Biomimetics 9 (3), 031002. doi: 10.1088/1748-3182/9/3/031002.

Nishimoto S, Bhushan B, (2013) Bioinspired self-cleaning surfaces with superhydrophobicity, superoleophobicity, and superhydrophilicity, RSC Advances 3, pp. 671-690.

Parker AR, Lawrence CR, (2001) Water capture by a desert beetle, Nature 414, pp. 33-34.

Sato O, Kubo S, Gu ZZ, (2009) Structural Color Films with Lotus Effects, Superhydrophilicity, and Tunable Stop-Bands, Accounts of Chemical Research 42 (1), pp. 1-10.

$\mathrm{Su}$ C, (2010) Facile fabrication of a lotus-effect composite coating via wrapping silica with polyurethane, Applied Surface Science 256 (7), pp. 2122-2127.

Vincent JFV, (2014) Chapter 17 - Biomimetic Materials, in Materials Experience: Fundamentals of Materials and Design, Karana E, Pedgley O, Rognoli V, (eds.), ButterworttHeinemann, pp. 235-246.

Vincent JFV, Owers P, (1986) Mechanical design of hedgehog spines and porcupine quills, Journal of Zoology, 210 (1), pp. 55-75.

Vukusic R, Sambles JR, (2003) Photonic structures in biology, Nature 424, pp. 852-855.

Wisdom KM, Watson JA, Qu X, Liu F, Watson GS, Chen C-H, (2013) Self-cleaning of superhydrophobic surfaces by self-propelled jumping condensate, PNAS 110 (20), pp. 7992-7997.

Wu D, Wang J-N, Wu S-Z, Chen Q-D, Zhao S, Zhang H, Sun H-B, Jiang L, (2011) Three-level biomimetic rice-leaf surfaces with controllable anisotropic sliding, Advanced Functional Materials 21, pp. 2927-2932.

Zhang H, Cai C, Liu W, Li W, Zhang J, Zhao N, Xu J, (2017) Recyclable polydimethylsiloxane network crosslinked by dynamic transesterification reaction, Scientific Reports 7, Article number 11833.

Zhang L, Zhong Y, Cha D, Wang P, (2013) A self-cleaning underwater superoleophobic mesh for oil-water separation, Scientific Reports 3, n. 2326. 
Español: La autolimpieza es una característica importante de muchas especies biológicas, ampliamente investigada en la literatura biomimética, con el objetivo de ofrecerla en materiales innovadores. Para tratar de resumir las diferentes propiedades de los materiales bioinspirados que tienen un efecto autolimpiante, se han propuesto diferentes modos de clasificación. En particular, se cita una especie paradigmática, por ejemplo, "efecto de loto", "efecto pétalo de rosa", etc., o se menciona una propiedad física, como superhidrofobicidad, supeoleofobia, etc. Este trabajo considera algunas diferencias modos en los que la naturaleza implementa la autolimpieza como una forma de interacción efectiva con el agua, dependiendo de las necesidades respectivas de las diversas especies. Con este objetivo, se ha considerado una muestra de diez especies, seleccionadas entre las que han sido más investigadas en la literatura biomimética. Luego se realiza un intento de clasificación, tratando de ofrecer información para el desarrollo de nuevos materiales inspirados en la naturaleza que ofrecen propiedades de autolimpieza en diferentes condiciones de aplicación.

Palabras clave: Autolimpieza - especies biológicas - literature biomimética - materiales - naturaleza.

Portugués: A autolimpeza é uma característica importante de muitas espécies biológicas, consideravelmente investigada na literatura biomimética, com o objetivo de oferecê-la em materiais inovadores. Para tentar resumir as diferentes propriedades de materiais bioinspirados com efeito de auto-limpeza, diferentes modos de classificação foram propostos. Em particular, ou uma espécie paradigmática é citada, por exemplo, "efeito de lótus", "efeito de pétala de rosa", etc., ou uma propriedade física é mencionada, como super-hidrofobicidade, super-oleofobicidade, etc. Este trabalho considera algumas diferenças. modos em que a natureza implementa a autolimpeza como forma de interação efetiva com a água, dependendo das respectivas necessidades das várias espécies. Para tanto, foi considerada uma amostra de dez espécies, dentre as que foram mais investigadas na literatura biomimética. É feita uma tentativa de classificação, tentando oferecer informações para o desenvolvimento de novos materiais inspirados na natureza, oferecendo propriedades autolimpantes em diferentes condições de aplicação.

Palavras chave: Auto-limpeza - espécies biológicas - literatura biomimética - materiais natureza.

[Las traducciones de los abstracts fueron supervisadas por el autor de cada artículo] 